\title{
Synthesis of new enantiopure poly(hydroxy)aminooxepanes as building blocks for multivalent carbohydrate mimetics
}

\author{
Léa Bouché, Maja Kandziora and Hans-Ulrich Reissig*
}

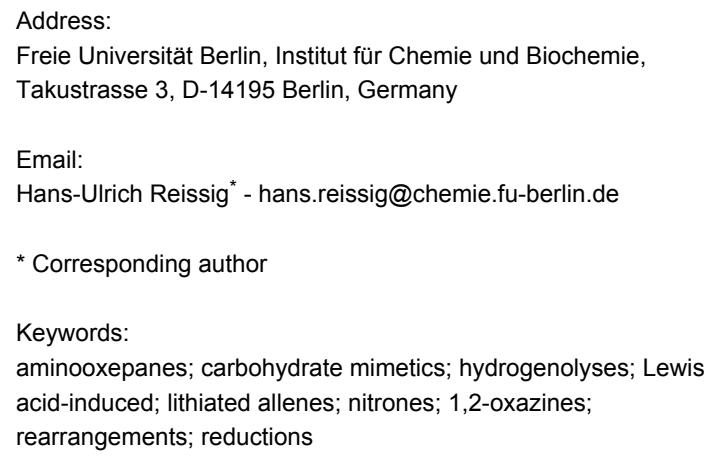

Beilstein J. Org. Chem. 2014, 10, 213-223.

doi:10.3762/bjoc. 10.17

Received: 24 August 2013

Accepted: 01 December 2013

Published: 20 January 2014

Associate Editor: J. N. Johnston

(c) 2014 Bouché et al; licensee Beilstein-Institut.

License and terms: see end of document.

\begin{abstract}
New compounds with carbohydrate-similar structure (carbohydrate mimetics) are presented in this article. Starting from enantiopure nitrones and lithiated TMSE-allene we prepared three 1,2-oxazine derivatives which underwent a highly stereoselective Lewis acid-induced rearrangement to give bicyclic products in good yield. Subsequent reductive transformations delivered a library of new poly(hydroxy)aminooxepane derivatives. The crucial final palladium-catalyzed hydrogenolysis of the 1,2-oxazine moiety was optimized resulting in a reasonably efficient approach to a series of new seven-membered carbohydrate mimetics.
\end{abstract}

\section{Introduction}

Since carbohydrates play a crucial role in biochemistry, compounds mimicking their structure and/or function (carbohydrate mimetics) have attracted great attention in academic research and in drug development [1-3]. These mimetics should not have the drawbacks of carbohydrates such as low binding affinity or instability [4,5]. Many carbohydrates and their mimetics contain pyran rings, however, the corresponding ring-expanded compounds, oxepanes, have been investigated only in a limited number of studies. Several oxepane units can be found in natural products, in particular as toxins in marine organisms or plants [6,7]. A few reports in the literature deal with sevenmembered polyhydroxylated ethers like septanosides (contain- ing an anomeric center) [8] as well as compounds without an acetal moiety. Known methods for the construction of the seven-membered polyhydroxylated oxacycle, are for instance cycloaddition [9-11] or cyclodehydration of commercially available alcohols [12-14]. The disadvantages of these methods are the lack of selectivity as well as of stereocontrol and hence other routes are needed. One interesting option is the pathway via oxepines [15-18] and the subsequent dihydroxylation or direct reduction of their $\mathrm{C}=\mathrm{C}$ double bond to give the corresponding oxepane derivatives $[19,20]$. Alternatively, oxepanes were also synthesized by the ring enlargement of their six-membered homologues $[21,22]$. Disappointingly, these methods 
often involve long reaction sequences and display sometimes restricted flexibility. A search for new stereoselective approaches is therefore highly desirable.

During the last years our group systematically studied a new approach to carbohydrate mimetics D [23-28]. The general approach is shown in Scheme 1: the chiral pool-derived nitrones A [29,30] undergo a [3+3]-cyclization with lithiated [2-(trimethylsilyl)ethoxy]allene (TMSE-allene) [31] as C-3 building block [32] to form the 3,6-dihydro- $2 H$-1,2-oxazines $\mathbf{B}$; subsequent Lewis acid-promoted reactions [23] lead to the highly functionalized bicyclic 1,2-oxazinones $\mathbf{C}$ which can be regarded as protected aminopolyol precursors offering the option for plenty of selective transformations [27,28]; after reductive steps the polyhydroxylated cyclic ethers $\mathbf{D}$ are obtained. The advantages of this route are the stereocontrol and the flexibility concerning the chain length. In 2005, Al-Harrasi synthesized the first tert-butyldimethylsilyl (TBS)-protected aminopyrans $(n=0)$ and aminooxepanes $(n=1)$ via this reaction route [23]. Several of the poly(hydroxy)aminopyrans [24] were connected to gold nanoparticles and the resulting multivalent conjugates showed extremely high binding to P- and L-selectine [33,34]. For the planned biological testing of the corresponding aminooxepanes as components of multivalent conjugates, we required the fully deprotected compounds. Moreover, it was desirable to have additional derivatives with different configurations or functional groups. In this article, we therefore describe the full details of our route to a series of new enantiopure poly(hydroxy)aminooxepanes with variations at the 2-, 5- and 7-position of the seven-membered cyclic ether $\mathbf{D}$.

\section{Results and Discussion}

The enantiopure ( $Z$ )-nitrones $\mathbf{3}, \mathbf{6}$ and $\mathbf{8}$ were synthesized essentially following known pathways [35] (Scheme 2 and Scheme 3). The new D-erythrose-derived nitrone 3 containing a $p$-bromophenyl moiety in the dioxolane ring was obtained in a straightforward manner (Scheme 2). Commercially available D-isoascorbic acid (1) was smoothly transformed in four steps into the ethyl ester $\mathbf{2}$. After protection of the free 1,2-diol unit of

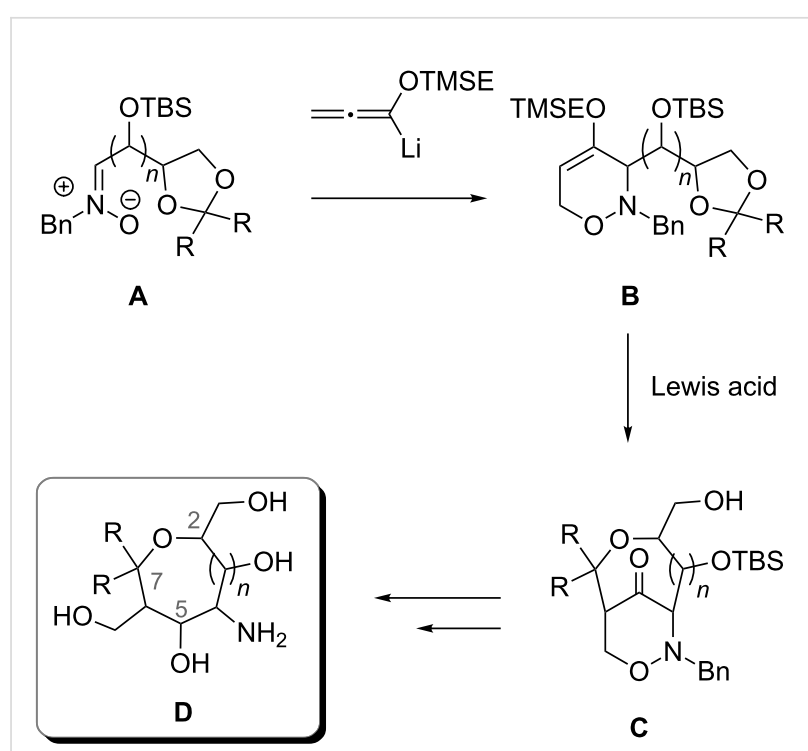

Scheme 1: General approach to enantiopure the poly(hydroxy)aminopyrans $\mathbf{D}(n=0)$ and the aminooxepanes $\mathbf{D}(n=1)$ by [3+3]-cyclization of the (Z)-nitrones $\mathbf{A}$ with lithiated TMSE-allene followed by Lewis acid-induced rearrangement of 3,6-dihydro- $2 H$-1,2-oxazines B. [TBS = tert-butyldimethylsilyl, TMSE = 2-(trimethylsilyl)ethyl]

1 employing $p$-bromobenzaldehyde dimethylacetal, the ring double bond was oxidatively cleaved to give the sodium carboxylate which was directly transformed into the corresponding ethyl ester [36]. Protection with a TBS-group proceeded quantitatively to gain $\mathbf{2}$ in very good overall efficacy. Final transformation into the desired nitrone $\mathbf{3}$ was achieved in $83 \%$ yield (over two steps) by reduction of the ester using DIBAL-H at low temperature, followed by condensation with $N$-benzylhydroxylamine according to a Dondoni protocol [29]. This route allows the synthesis of enantiopure nitrone $\mathbf{3}$ in multi-gram scale.

The enantiopure $(Z)$-configured nitrones $\mathbf{6 , 8}$ and $\mathbf{3}$ were treated with in situ lithiated TMSE-allene at $-78{ }^{\circ} \mathrm{C}$ furnishing the expected 1,2-oxazines syn-7 [37], syn-9 and syn-10 in high yields and with excellent diastereoselectivities (Scheme 3). The

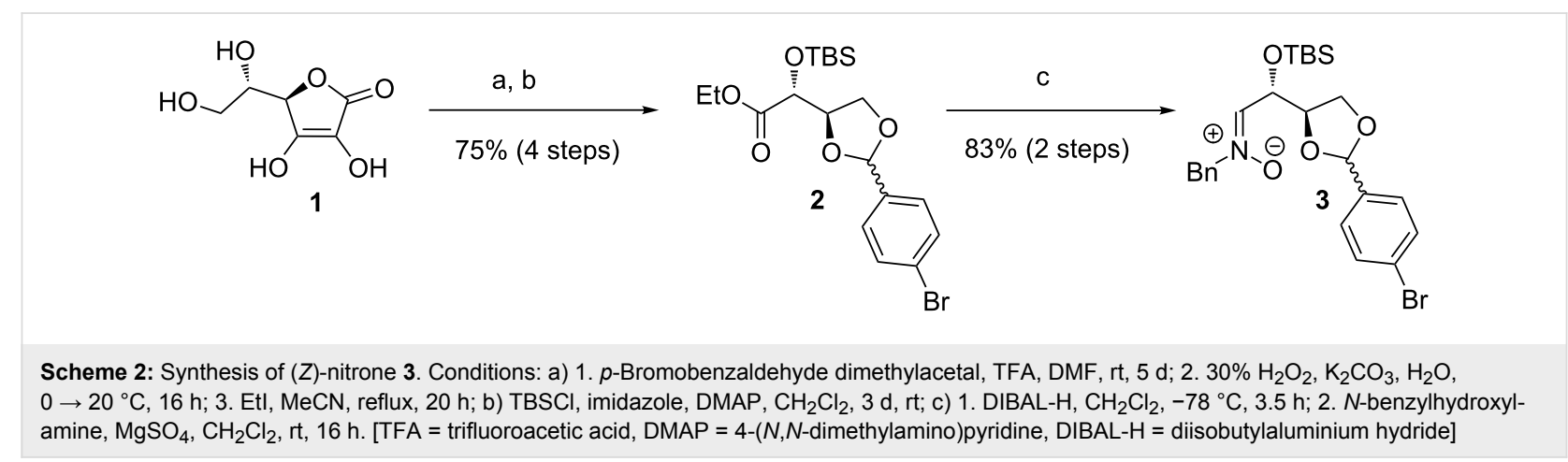




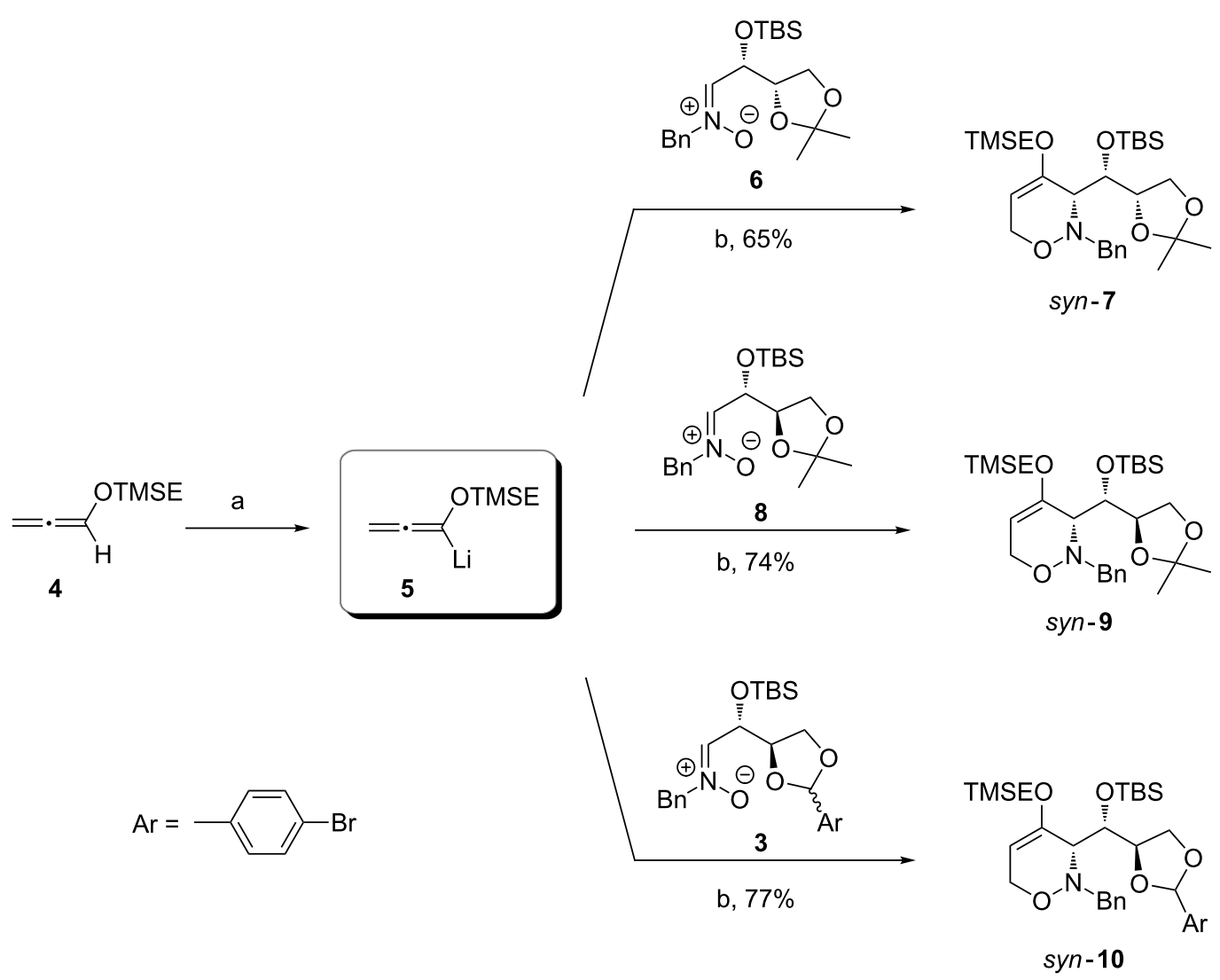

Scheme 3: Synthesis of 1,2-oxazines syn-7, syn-9 and syn-10. Conditions: a) $n$-BuLi, THF, $-40{ }^{\circ} \mathrm{C}, 15 \mathrm{~min}$; b) 1 . THF, $-78{ }^{\circ} \mathrm{C}, 1.5$ to $3 \mathrm{~h} ; 2$. $\mathrm{H}_{2} \mathrm{O}$, $1 \mathrm{~h},-78^{\circ} \mathrm{C} \rightarrow \mathrm{rt}$. The syn:anti ratios were determined by ${ }^{1} \mathrm{H}$ NMR spectroscopic analysis of the crude products and are all $>95: 5$ (see Supporting Information File 2).

nitrone 3 was used as a 96:4 mixture (with respect to the stereogenic center of the 1,3-dioxolane ring) and it could therefore provide four diasteromers of 1,2-oxazine syn-10 (two major syn- and two minor anti-diasteromeres), but only a single synstereoisomer (with respect to C-3 of the 1,2-oxazine ring) was isolated after column chromatography. A product derived from the minor isomer of nitrone 3 was not detected and was apparently lost during the reaction or the purification. Since the stereogenic center of the 1,3-dioxolane ring is converted into an $\mathrm{sp}^{2}$-hybridized carbon during the Lewis acid-induced ring opening, the configuration of syn-10 was not assigned at this center.

We discussed the mechanism of this [3+3]-cyclization in detail including possible side-reactions in an earlier report [31]. The observed high syn-diastereoselectivities are in accordance with our previously published results and were supported by an $\mathrm{X}$-ray analysis of syn-7 [37]. We conclude from our observations that the formation of 1,2-oxazines from nitrones $\mathbf{3 , 6}$ and $\mathbf{8}$ is mainly steered by the stereogenicity at the $\alpha$-carbon $(1,2-$ induction) $[30,31]$, whereas the stereogenic center at the $\beta$-carbon (1,3-induction) has no or negligible influence. A few $s y n$-selective additions of other nucleophiles to nitrones with two stereogenic centers similar to 6 or $\mathbf{8}$ were reported in the literature $[38,39]$. A preferred transition structure as depicted in Figure 1 plausibly explains our results. The silyloxy group at the $\alpha$-carbon occupies an orthogonal position, the substituent $R$ is close to the nitrone hydrogen substituent and the lithiated allene attacks from the Re-side of the nitrone (Felkin-Anh model for nitrones as proposed by Dondoni et al. [30]). An additional coordination of the lithium cation to the nitrone oxygen is possible.

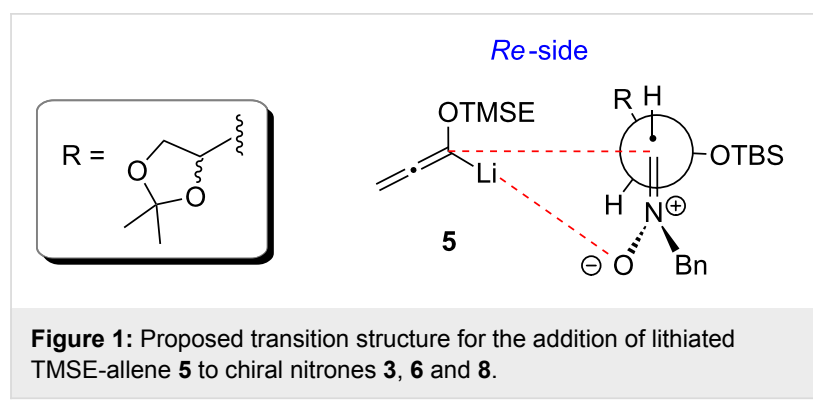


The Lewis acid-induced rearrangements of 1,2-oxazines syn-7, syn-9 and syn-10 were achieved in moderate to good yields using TMSOTf as promoter (Scheme 4). A higher yield of 73\% was achieved for the $p$-bromophenyl derivative $\mathbf{1 3}$ (isolated as a single diastereomer) which may be due to the stabilized carbenium ion formed at the benzylic position.<smiles>CCOC(C)(C)C</smiles><smiles>C[13CH3]</smiles>

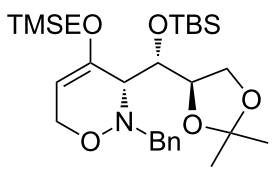<smiles>C[13CH3]</smiles>
syn-9

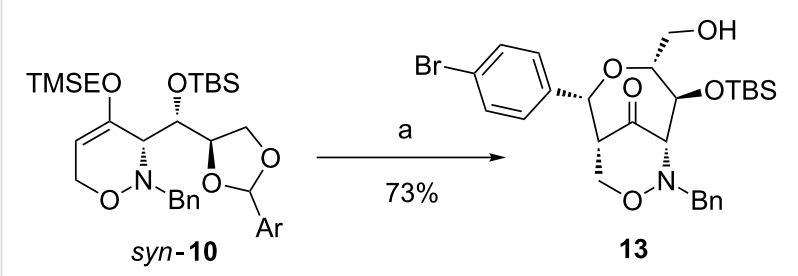

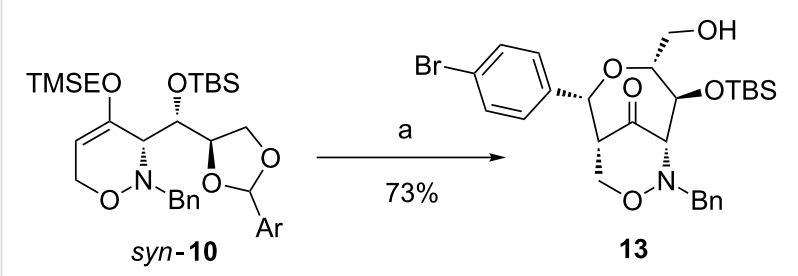

11

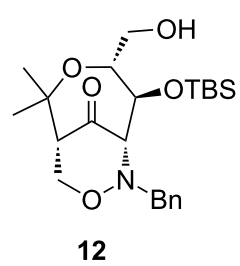

Scheme 4: Synthesis of ketones 11, 12 and 13 with a bicyclic 1,2oxazine skeleton by Lewis acid-induced rearrangement. Conditions: a) 1. TMSOTf, $\mathrm{CH}_{2} \mathrm{Cl}_{2},-5{ }^{\circ} \mathrm{C}, 5$ to $6 \mathrm{~h}$; 2. aq $\mathrm{NH}_{3}$, rt, $10 \mathrm{~min}$. [TMSOTf = trimethylsilyl trifluoromethanesulfonate]

This rearrangement presents a relatively rare example of an intramolecular aldol-like reaction of an enol ether with an activated acetal (which may also be regarded as a special case of a Prins reaction) forming a seven-membered ring. We propose a Zimmerman-Traxler-type transition state (Scheme 5), placing the aryl group $R^{2}\left(R^{1}=H\right)$ in the sterically more favorable pseudo-equatorial position in the reaction leading to compound
13 (for other Lewis acid-mediated formations of seven membered oxacycles, see references [40,41]).

The relative configuration of the newly formed stereogenic center at the $\mathrm{C}-2$ position of $\mathbf{1 3}$ was successfully determined by NOE experiments. By irradiation of the 2-H proton (Figure 2) several dipolar couplings with $1-\mathrm{H}, 4-\mathrm{H}$ and with one proton of the $p$-bromophenyl group were observed. For this reason, it is assumed that the 2-H proton of $\mathbf{1 3}$ is cis-orientated to the 1-H and $4-\mathrm{H}$ protons and consequently shows an $(R)$-configuration.

Ketones 11, 12 and $\mathbf{1 3}$ were subsequently smoothly reduced with sodium borohydride in ethanol. In all cases, only one diastereomer (hydroxy group at C-10 with an $S$-configuration) was isolated (Scheme 6). These results are in accordance with previous observations obtained for the corresponding TBS-protected derivatives [42] suggesting that a preferred conformation of the seven-membered ring favors the hydride attack only from the $R e$-side. The $S i$-side (back-side) attack is probably hindered by the bulky OTBS group (also see Scheme 5). The configurational assignments are in accordance with NOE experiments performed with the alcohol derived from ketone $\mathbf{1 3}$ (precursor of 16), where dipolar couplings have been observed between the $10-\mathrm{H}$ and $9-\mathrm{H}$ protons $\left(\mathrm{CH}_{2}\right.$ next to the $\mathrm{N}-\mathrm{O}$ bond). Finally, the TBS-groups were removed under standard conditions furnishing triols 14, 15 and 16 in high yields.

The free primary hydroxy group of bicyclic ketone $\mathbf{1 1}$ was propargylated in $71 \%$ yield employing propargylic bromide under standard conditions (Scheme 7). After reduction of the carbonyl group [43] and TBS cleavage, propargylic ether 18 was obtained ( $88 \%$ yield over two steps) [44]. The alkyne moiety provides options for further transformations, e.g. Sonogashira reactions, Glaser couplings or 1,3-dipolar cycloadditions (click reactions) [45].

We were also interested in the preparation of the bicyclic azide $\mathbf{2 4}$ and hence the primary hydroxy group of $\mathbf{1 1}$ was converted into mesylate 19 followed by a reduction of the carbonyl group

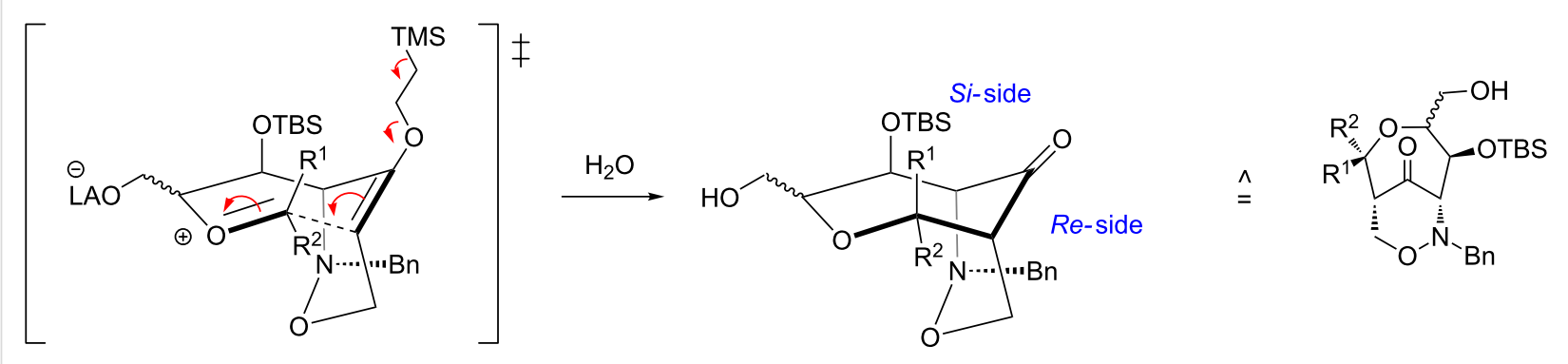




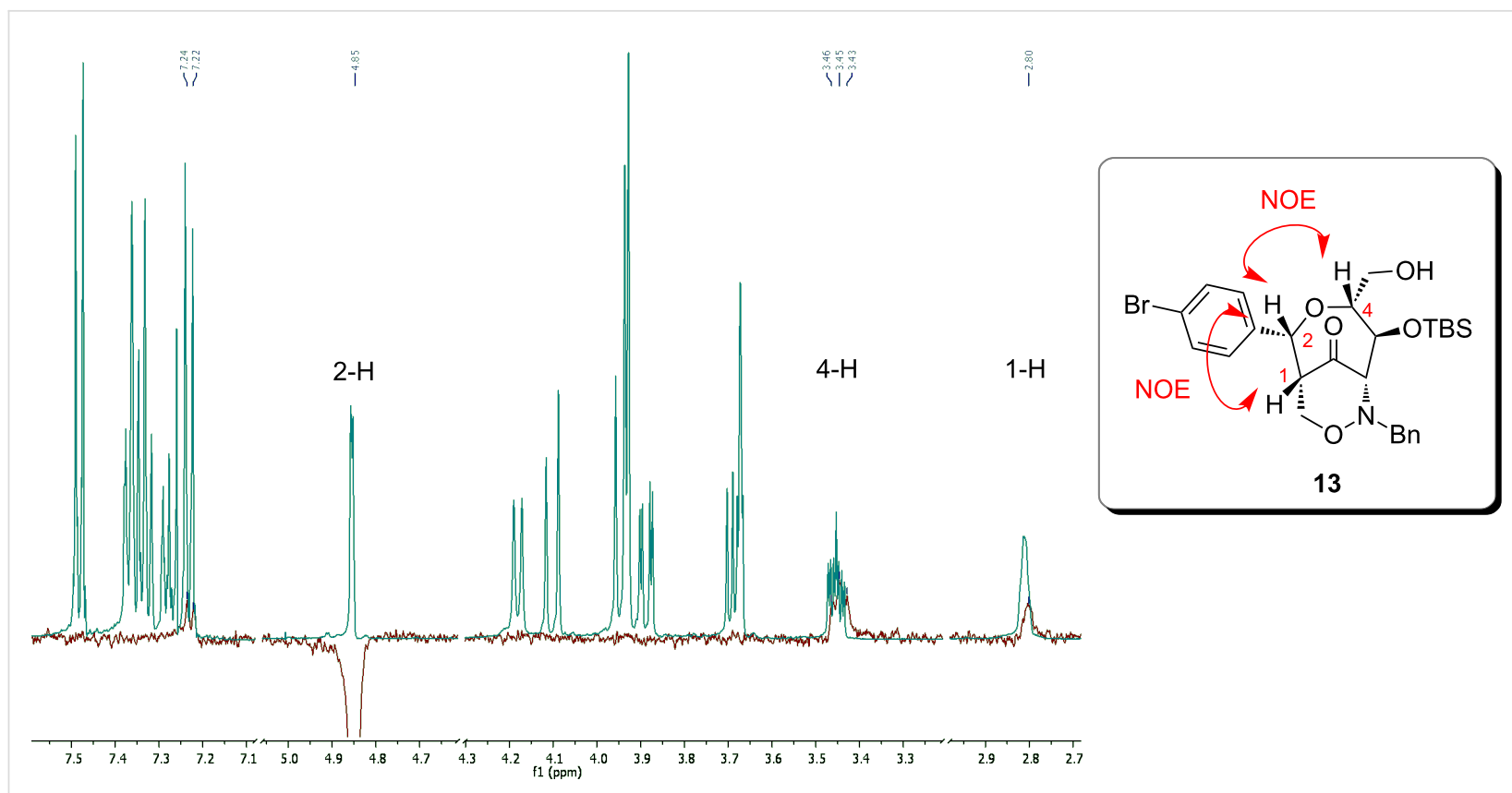

Figure 2: GOESY-NMR spectrum $\left(\mathrm{CDCl}_{3}, 500 \mathrm{MHz}\right)$ of bicyclic 1,2-oxazine 13: irradiation of the 2-H proton. [GOESY = gradient enhanced nuclear Overhauser effect spectroscopy]

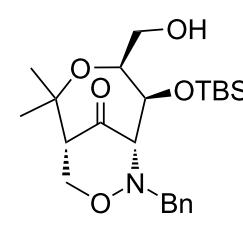

11

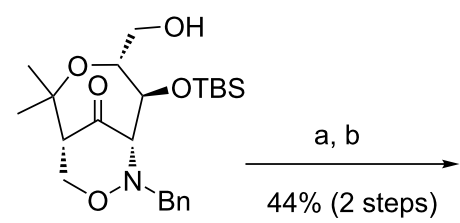

12<smiles>OC[C@H]1O[C@H]([Al])[C@@H]2CON(Cc3ccccc3)[C@@H]2[C@@H]1[OH2+]</smiles>

13

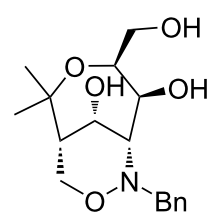

14

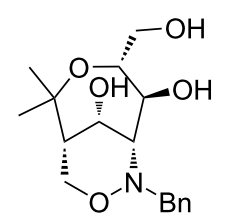

15

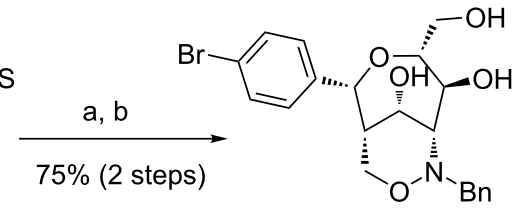

16
Scheme 6: Synthesis of triols 14,15 and 16 by reduction of the carbonyl group and deprotection. Conditions: a) $\mathrm{NaBH}_{4}, \mathrm{EtOH}, 0{ }^{\circ} \mathrm{C}$, $40 \mathrm{~min}$ to $16 \mathrm{~h}$; b) TBAF ( $1 \mathrm{M} \mathrm{THF}$ ), THF, $0{ }^{\circ} \mathrm{C}, 10 \mathrm{~min}$ to $3.5 \mathrm{~h}$. [TBAF $=$ tetra- $n$-butylammonium fluoride]

(Scheme 8). The attempted nucleophilic substitution by sodium azide gave a mixture of two products: the desired TBS-protected azide $\mathbf{2 1}$ and an unexpected side product $\mathbf{2 2}$. To over- come the formation of this side product, the introduction of the azido group was directly performed with mesylate 19 . Since the nucleophilic substitution of $\mathbf{1 9}$ into $\mathbf{2 3}$ gave only moderate yields with low reproducibility (from 39-67\%), this step was optimized using Mitsunobu conditions with diphenylphosphoryl azide according to a protocol by Bose [46]. The desired bicyclic azide $\mathbf{2 3}$ was now isolated in 79\% yield and its subsequent reduction and deprotection with TBAF gave compound 24 in essentially quantitative yield (over two steps). After protection of the two hydroxy substituents of $\mathbf{2 4}$ with TBSgroups, a Staudinger reaction was performed, which furnished bicyclic 1,2-oxazine derivative $\mathbf{2 5}$ with a primary amino group in $80 \%$ yield (over two steps).

Next we wanted to synthesize the unexpectedly formed unique tricyclic 1,2-oxazine 20 with higher efficacy. After reduction of 19 with sodium borohydride the intermediate alcohol was heated with triethylamine (to avoid the deprotection of the TBSgroup) and compound $\mathbf{2 0}$ was obtained in $\mathbf{7 5 \%}$ yield (over three steps).

The previously isolated unprotected triols 14, 15 and 20 were subjected to standard hydrogenolysis conditions using palladium on charcoal in order to remove the $N$-benzyl group and to cleave the $\mathrm{N}-\mathrm{O}$ bond $[47,48]$ in one step. This process is often challenging due to the difficult control of the various reaction parameters and also because of the high polarity of the newly formed compounds. According to the experience of our group 


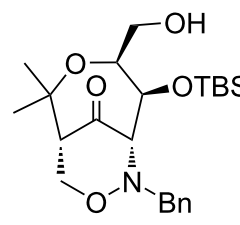

11

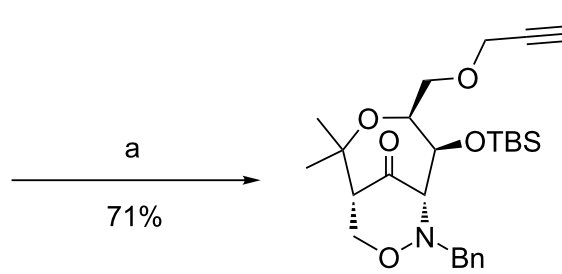

17

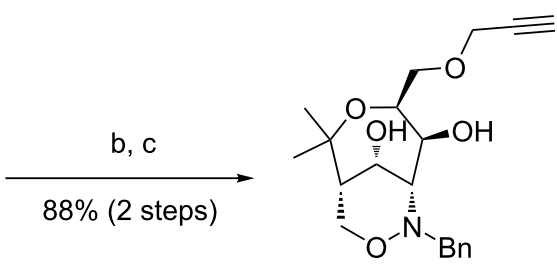

18

Scheme 7: Synthesis of propargylic ether 18. Conditions: a) propargyl bromide, $\mathrm{NaOH}, \mathrm{TBAl}, \mathrm{H}_{2} \mathrm{O} / \mathrm{CH}_{2} \mathrm{Cl}_{2},-20^{\circ} \mathrm{C} \rightarrow \mathrm{rt}, 7 \mathrm{~d}$; b) $\mathrm{NaBH} \mathrm{H}_{4}, \mathrm{EtOH}, 0{ }^{\circ} \mathrm{C}$, $4 \mathrm{~h}$; c) TBAF (1 M THF), THF, $0{ }^{\circ} \mathrm{C} \rightarrow \mathrm{rt}, 3 \mathrm{~d}$. [TBAl = tetra- $n$-butylammonium iodide]

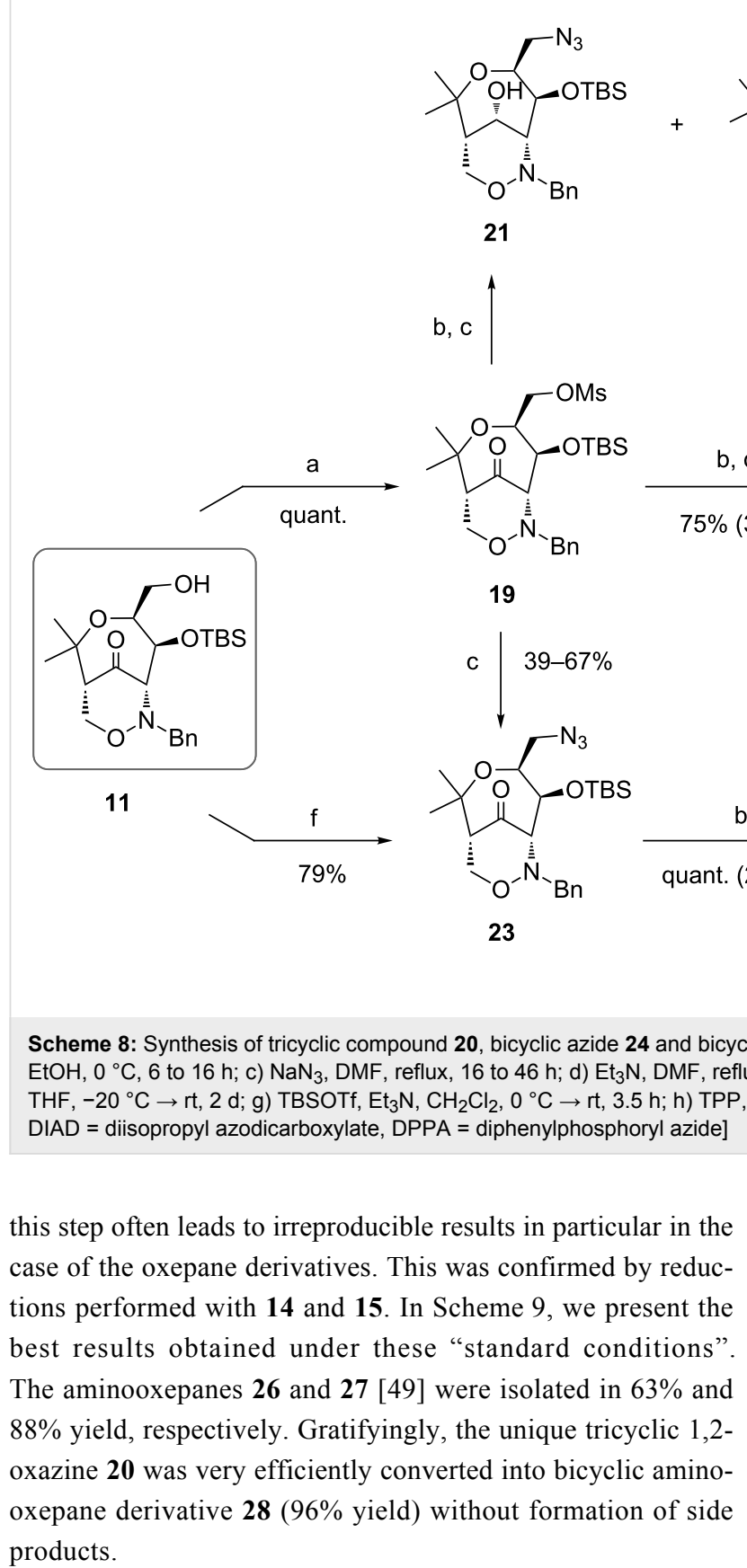

The irreproducible results with $\mathbf{1 4}$ and $\mathbf{1 5}$ are probably due to the formation of side products such as $\mathbf{2 9}$ and $\mathbf{3 0}$ isolated in low quantities (proposed structures are presented in Figure 3). The ${ }^{1} \mathrm{H}$ NMR spectra of all observed side products show signals at ca. 4.5 ppm, typically appearing as two symmetric doublets (AX system) with a coupling constant of $5.7 \mathrm{~Hz}$. These observations suggest the presence of a methylene bridge at the aminooxepane skeleton. The position of the methylene bridge was only determined for side product 27 using HMBC NMR spec- 


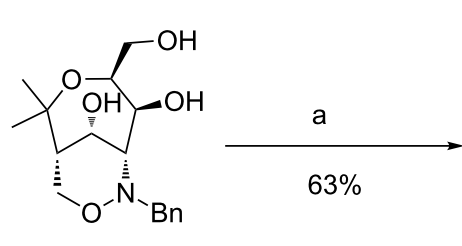

14<smiles>CC1(C)O[C@@H](CO)C(O)C2C1[C@H]1CON(Cc3ccccc3)[C@H]21</smiles>

15

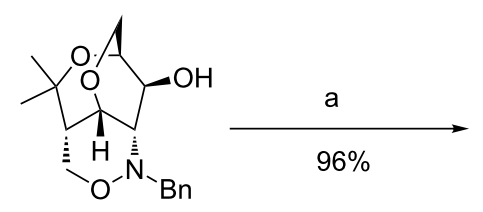

20<smiles>CC1(C)OC(CO)C(O)[C@@H](N)[C@H]1O</smiles>

26<smiles>CC1(C)O[C@H](CO)C(O)[C@@H](N)[C@H]1O</smiles>

27<smiles>CC1(C)OC2CC(O)C(O)C(O2)C1[C@H](N)CO</smiles>

28
Scheme 9: Hydrogenolyses of bicyclic and tricyclic 1,2-oxazines 14, 15 and 20 to aminooxepanes 26,27 and 28. Conditions: a) $\mathrm{H}_{2}, \mathrm{Pd} / \mathrm{C}$, $\mathrm{MeOH}, \mathrm{rt}, 18 \mathrm{~h}$.<smiles>CC1(C)OC(CO)C2OCNC2C1O</smiles>

29<smiles>CC1(C)O[C@H](CO)C2OCNC2C1O</smiles>

30
Figure 3: Proposed structures of the observed side products 29 and 30 during the hydrogenolyses of 14 and 15.

troscopy which shows a small coupling between one proton of the methylene bridge and C-3 (position of the alcohol). We assume that they are formed by in situ generated formaldehyde (dehydrogenation of methanol) [50-53] and subsequent aminal formation with aminooxepanes $\mathbf{2 6}$ and $\mathbf{2 7}$. The aminoalcohol 28 seems not to form the corresponding compounds. We suppose that bicyclic compound $\mathbf{2 8}$ is more strained and hence the formation of a third ring may be unfavorable.

In order to avoid this side-reaction we performed hydrogenolysis experiments in alternative solvents, e.g. with ethanol or isopropanol, but small amounts of the corresponding side products were also observed in these experiments. Unpolar solvents were not suitable for the hydrogenolysis, probably due to the low solubility and conversion of the fairly polar starting materials or intermediates. After these problems we tried to diminish the nucleophilicity of the amino group by addition of acid since this protocol has proved to be advantageous in other reduction processes of amines [54]. Acetic acid in methanol (1:5) was a good medium for our reductions and substrate 14 was now smoothly reduced under hydrogen atmosphere with palladium on charcoal. After filtration through a pad of acidic DOWEX $^{\circledR}$ resin followed by elution with aqueous ammonia the clean poly(hydroxy)aminooxepane $\mathbf{2 6}$ was obtained in $90 \%$ yield (Scheme 10). Under these optimized reaction conditions other hydrogenolyses were studied. $p$-Bromophenylsubstituted triol 16 was transformed into the corresponding poly(hydroxy)aminooxepane derivative 31 in $73 \%$ yield. As expected, the bromo substituent of the aryl group was also reductively removed delivering a phenyl group in product 31 . Propargylic ether $\mathbf{1 8}$ was converted in quantitative yield into $n$-propyl ether 32. Remarkably, the hydrogenolysis of bicyclic azide 24 smoothly furnished the diaminooxepane 33 in $72 \%$ yield. The results obtained using these new conditions are promising for other $\mathrm{N}-\mathrm{O}$ cleavages of polar 1,2-oxazine derivatives. Furthermore, due to the newly formed amino group the prepared poly(hydroxy)aminooxepanes offer the option to<smiles>CC1(C)O[C@H](CO)[C@@H](O)[C@H]2[C@H]1CON2Cc1ccccc1</smiles>

14
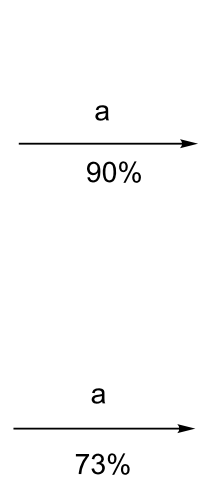<smiles>CC1(C)OC(CO)C(O)[C@@H](N)[C@H]1O</smiles>

26
16

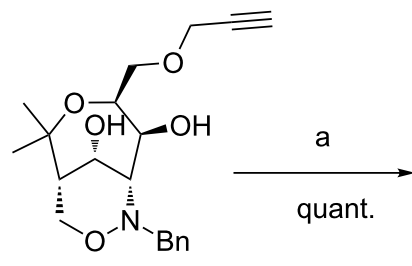

18<smiles>CC1(C)OC2(CN)C(O)C3[C@H]1CON(Cc1ccccc1)[C@H]32</smiles>

24<smiles>OC[C@H]1O[C@@H]([125I])[C@@H]2CON(Cc3ccccc3)[C@H]1[C@H]2O</smiles>
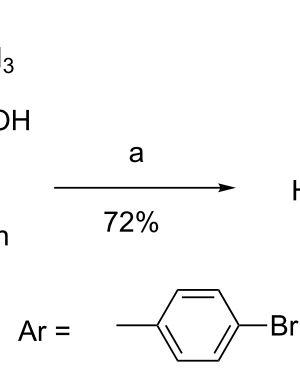<smiles>N[C@@H]1[C@H](O)[C@H](c2ccccc2)O[C@@H](CO)[C@@H]1O</smiles>

31<smiles>CCCOC[C@H]1OC(C)(C)[C@@H](CO)[C@@H](O)[C@H](N)[C@H]1O</smiles>

32<smiles>CC1(C)OC(CN)C(O)[C@@H](N)[C@H]1O</smiles>

33
Scheme 10: Hydrogenolyses of bicyclic 1,2-oxazines to aminooxepanes 26, $\mathbf{3 1}$ and $\mathbf{3 2}$ and to diaminooxepane $\mathbf{3 3}$ under optimized conditions. Conditions: a) 1 . $\mathrm{H}_{2}, \mathrm{Pd} / \mathrm{C}, \mathrm{MeOH} / \mathrm{AcOH}=5: 1$, rt, $17 \mathrm{~h}$; 2. DOWEX ${ }^{\circledR} \mathrm{H}^{+}$; 3. aq $\mathrm{NH}_{3}$. 
selectively perform reductive aminations or Schotten-Baumann reactions. All these processes can lead to new carbohydrate mimetics, also in a multivalent fashion.

\section{Conclusion}

In summary, the presented route employs the following key steps: Dondoni protocol for nitrone synthesis, $[3+3]$-cyclization with lithiated TMSE-protected allene, Lewis acid-induced rearrangement and reductive processes including a final hydrogenolysis. The new highly functionalized poly(hydroxy)aminooxepanes were thereby successfully synthesized in a highly stereocontrolled manner. The obtained compounds are potential carbohydrate mimetics and supplement the already studied sixmembered homologues $[33,34]$. The introduction of new functional groups such as alkynyl or azido substituents at the bicyclic skeleton will also allow further transformations such as click reactions or palladium-catalyzed couplings. We expect that the newly prepared aminooxepanes or their multivalent conjugates will have interesting properties and possibly biological activities, e.g. as selectine inhibitors, which is currently investigated.

\section{Experimental}

General methods: See Supporting Information File 1

\section{Typical procedure for the preparation of syn-} 1,2-oxazines by addition of lithiated TMSEallene to chiral nitrones (procedure 1) (3S,1'S,4' 'S)-2-Benzyl-1'-[(tert-butyldimethylsiloxy)-(2', ,2'dimethyl-1, , 3,',dioxolan-4,'-yl)methyl]-4-[2,,', (trimethylsilyl)ethoxy]-3,6-dihydro-2H-1,2-oxazine (syn-7): Analogous to literature [31], under argon atmosphere TMSEallene 4 (5.00 g, $32.0 \mathrm{mmol})$ was dissolved in dry THF $(60 \mathrm{~mL})$. The slightly yellow solution was cooled to $-40{ }^{\circ} \mathrm{C}$ and $n$-BuLi (2.5 $\mathrm{M}$ in hexanes; $10.2 \mathrm{~mL}, 25.6 \mathrm{mmol}$ ) was slowly added. After $15 \mathrm{~min}$, the resulting strong-yellow mixture was cooled to $-78{ }^{\circ} \mathrm{C}$, and a solution of nitrone $6(4.00 \mathrm{~g}, 10.5 \mathrm{mmol})$ in dry THF $(60 \mathrm{~mL})$ was added dropwise. The reaction mixture turned pink, then orange and later dark red. After stirring at this temperature for $2.5 \mathrm{~h}$, the reaction mixture was quenched with water $(40 \mathrm{~mL})$ and left to warm to $\mathrm{rt}$ and then extracted with $\mathrm{Et}_{2} \mathrm{O}(3 \times 65 \mathrm{~mL})$. The combined organic layers were washed with brine, dried with $\mathrm{Na}_{2} \mathrm{SO}_{4}$, filtered through cotton and the solvent was removed in vacuo. Crude material [orange solid, $4.00 \mathrm{~g}$; syn:anti-7 $>95: 5$ and corresponding diene (see Supporting Information File 1) $<2 \%$ ] was purified by column chromatography (silica gel, hexanes/EtOAc 17:0.5) to yield syn-7 (3.69 g, 65\%, lit. [23,37] 71\%, syn:anti-7 94:6) as a paleyellow solid; mp $102-105{ }^{\circ} \mathrm{C}$; TLC (silica gel, hexanes/EtOAc 8:1) $R_{\mathrm{f}} 0.34 ;{ }^{1} \mathrm{H} \mathrm{NMR}\left(700 \mathrm{MHz}, \mathrm{CDCl}_{3}\right) \delta 0.02$ (s, 3H, SiMe), 0.06 (s, 9H, $\mathrm{SiMe}_{3}$ ), 0.08 (s, 3H, SiMe), 0.87 (s, 9H, Sit-Bu),
$1.00,1.09$ (AB part of $\mathrm{ABXY}$ system, $J_{\mathrm{AX}}=5.2 \mathrm{~Hz}$, $J_{\mathrm{BY}}=6.7 \mathrm{~Hz}, J_{\mathrm{AY}}=10.2 \mathrm{~Hz}, J_{\mathrm{BX}}=10.8 \mathrm{~Hz}, J_{\mathrm{AB}}=14.0 \mathrm{~Hz}$, $1 \mathrm{H}$ each, 2",'-H), 1.28, 1.34 (2 s, 3H each, Me), $2.78\left(\mathrm{~m}_{\mathrm{c}}, 1 \mathrm{H}\right.$, 3-H), 3.12, 3.19 (AB part of ABX-system, $J_{\mathrm{AX}}=6.6 \mathrm{~Hz}$, $J_{\mathrm{BX}} \approx J_{\mathrm{AB}}=7.8 \mathrm{~Hz}, 1 \mathrm{H}$ each, 5',-H), 3.78, 3.83 (XY part of $\mathrm{ABXY}$ system, $J_{\mathrm{AX}}=5.2 \mathrm{~Hz}, J_{\mathrm{BY}}=6.7 \mathrm{~Hz}, J_{\mathrm{XY}}=8.5 \mathrm{~Hz}$, $J_{\mathrm{AY}}=10.2 \mathrm{~Hz}, J_{\mathrm{BX}}=10.8 \mathrm{~Hz}, 1 \mathrm{H}$ each, $\left.1,{ }^{\prime}, \mathrm{H}\right), 3.86(\mathrm{~d}$, $\left.J=12.5 \mathrm{~Hz}, 1 \mathrm{H}, \mathrm{NCH}_{2}\right), 3.87\left(\mathrm{dd}, J=3.5,8.0 \mathrm{~Hz}, 1 \mathrm{H}, 1^{\prime}-\mathrm{H}\right)$, 4.14* (d, $\left.J=12.5 \mathrm{~Hz}, 1 \mathrm{H}, \mathrm{NCH}_{2}\right), 4.14 *(\mathrm{dd}, J=3.5,15.1 \mathrm{~Hz}$, $1 \mathrm{H}, 6-\mathrm{H}), 4.25$ (dt, $J \approx 6.6,8.0 \mathrm{~Hz}, 1 \mathrm{H}, 4$ ' '-H), 4.46 (td, $J \approx 2.0$, $15.1 \mathrm{~Hz}, 1 \mathrm{H}, 6-\mathrm{H}), 4.81(\mathrm{dd}, J=2.0,3.5 \mathrm{~Hz}, 1 \mathrm{H}, 5-\mathrm{H}), 7.28$, 7.33, $7.38\left(3 \mathrm{~m}_{\mathrm{c}}, 1 \mathrm{H}, 2 \mathrm{H}, 2 \mathrm{H}, \mathrm{Ph}\right) \mathrm{ppm}$, * overlapping signals; ESI-TOF $(\mathrm{m} / \mathrm{z}):[\mathrm{M}+\mathrm{H}]^{+}$calcd for $\mathrm{C}_{28} \mathrm{H}_{50} \mathrm{NO}_{5} \mathrm{Si}_{2}, 536.3222$; found, 536.3289. The analytical data are in accordance with literature [23,37]. Characteristic signals of anti-7: ${ }^{1} \mathrm{H} \mathrm{NMR}$ $\left(700 \mathrm{MHz}, \mathrm{CDCl}_{3}\right): \delta 1.33,1.36(2 \mathrm{~s}, 3 \mathrm{H}$ each $), 4.08$ $(\mathrm{t}, J \approx 6.3 \mathrm{~Hz}, 1 \mathrm{H}, 6-\mathrm{H}), 4.29\left(\mathrm{~m}_{\mathrm{c}}, 1 \mathrm{H}, 4{ }^{\prime}{ }^{\prime}-\mathrm{H}\right), 4.76\left(\mathrm{~m}_{\mathrm{c}}, 1 \mathrm{H}\right.$, 5-H) ppm.

\section{Typical procedure for the Lewis acid-induced rearrangement (procedure 2)}

$(1 R, 4 S, 5 S, 6 S)$-7-Benzyl-5-(tert-butyldimethylsiloxy)-4(hydroxymethyl)-2,2-dimethyl-3,8-dioxa-7-azabicyclo[4.3.1]decan-10-one (11): Analogous to literature [23,37], under argon atmosphere 1,2-oxazine syn-7 (2.00 g, $3.73 \mathrm{mmol}$, syn:anti 94:6) was dissolved in dry $\mathrm{CH}_{2} \mathrm{Cl}_{2}(32 \mathrm{~mL})$. The solution was cooled to $-5{ }^{\circ} \mathrm{C}$ and TMSOTf $(1.35 \mathrm{~mL}, 7.46 \mathrm{mmol})$ was slowly added. After $5.5 \mathrm{~h}$ stirring at $0{ }^{\circ} \mathrm{C}$, the dark red mixture was quenched with a solution of aq ammonia (5\%) turning yellow. Work-up was performed with $\mathrm{CH}_{2} \mathrm{Cl}_{2}(3 \times 30 \mathrm{~mL})$. The combined organic layers were washed with brine, dried with $\mathrm{Na}_{2} \mathrm{SO}_{4}$, filtered through cotton and the solvent was removed in vacuo. The crude material (orange oil, $2.05 \mathrm{~g}$ ) was purified by column chromatography (silica gel, hexanes/EtOAc 5:1 to 4:1) to yield 11 ( $851 \mathrm{mg}, 53 \%$, lit. [23] 55\%) as a pale-yellow oil; TLC (silica gel, hexanes/EtOAc $2: 1$ ) $R_{\mathrm{f}} 0.48 ;{ }^{1} \mathrm{H}$ NMR $\left(500 \mathrm{MHz}, \mathrm{CDCl}_{3}\right) \delta-0.09,-0.02(2 \mathrm{~s}, 3 \mathrm{H}$ each, SiMe), 0.86 (s, 9H, Sit-Bu), 1.37, 1.38 (2 s, 3H each, Me), 1.72 (bs, 1H, $\mathrm{OH}), 2.57\left(\mathrm{~m}_{\mathrm{c}}, 1 \mathrm{H}, 1-\mathrm{H}\right), 3.37\left(\mathrm{~m}_{\mathrm{c}}, 1 \mathrm{H}, 6-\mathrm{H}\right), 3.56,3.67(\mathrm{AB}$ part of $\mathrm{ABX}$ system, $J_{\mathrm{AX}}=4.5 \mathrm{~Hz}, J_{\mathrm{BX}}=8.1 \mathrm{~Hz}$, $J_{\mathrm{AB}}=10.9 \mathrm{~Hz}, 1 \mathrm{H}$ each, 4- $\mathrm{CH}_{2}$ ), 3.94 (A part of AB system, $\left.J_{\mathrm{AB}}=13.4 \mathrm{~Hz}, 1 \mathrm{H}, \mathrm{NCH}_{2}\right), 4.11-4.13(\mathrm{~m}, 4 \mathrm{H}, 5-\mathrm{H}, 9-\mathrm{H}$, $\left.\mathrm{NCH}_{2}\right), 4.58$ (dd, $\left.J=4.5,8.1 \mathrm{~Hz}, 1 \mathrm{H}, 4-\mathrm{H}\right), 7.26-7.29(\mathrm{~m}, 5 \mathrm{H}$, $\mathrm{Ph}) \mathrm{ppm}$; ESI-TOF $(\mathrm{m} / \mathrm{z}):[\mathrm{M}+\mathrm{H}]^{+}$calcd for $\mathrm{C}_{23} \mathrm{H}_{38} \mathrm{NO}_{5} \mathrm{Si}$, 436.2514; found, 436.2553. The analytical data are in accordance with literature $[23,37]$.

\section{Typical procedure for ketone reduction with $\mathrm{NaBH}_{4}$ (procedure 3)

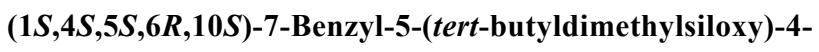 (hydroxymethyl)-2,2-dimethyl-3,8-dioxa-7-azabicyclo-}


[4.3.1]decan-10-ol: Under argon atmosphere ketone 11 (703 mg, $1.61 \mathrm{mmol})$ was dissolved in dry EtOH $(26 \mathrm{~mL})$. The solution was cooled to $0{ }^{\circ} \mathrm{C}$ and $\mathrm{NaBH}_{4}(119 \mathrm{mg}, 3.15 \mathrm{mmol})$ was added in portions. After stirring at $0{ }^{\circ} \mathrm{C}$ for $4 \mathrm{~h}$, the solvent was removed in vacuo. The crude material was dissolved in $\mathrm{CH}_{2} \mathrm{Cl}_{2}(20 \mathrm{~mL})$ and then extracted with $\mathrm{CH}_{2} \mathrm{Cl}_{2}(3 \times 25 \mathrm{~mL})$. The combined organic layers were washed with brine, dried with $\mathrm{Na}_{2} \mathrm{SO}_{4}$, filtered through cotton and the solvent was removed in vacuo to yield the corresponding alcohol (704 mg, quant.) as a colorless solid; melting range $132-137^{\circ} \mathrm{C}$; $[\alpha]_{\mathrm{D}}^{22}-61.1\left(c 0.63, \mathrm{CHCl}_{3}\right)$; TLC (silica gel, hexanes/EtOAc 2:1) $R_{\mathrm{f}} 0.58 ;{ }^{1} \mathrm{H}$ NMR $\left(700 \mathrm{MHz}, \mathrm{CDCl}_{3}\right) \delta-0.09,-0.04(2 \mathrm{~s}$, $3 \mathrm{H}$ each, SiMe), 0.88 (s, 9H, Sit-Bu), 1.32, 1.53 (2 s, 3H each, Me), 1.75 (bs, 1H, 4-OH), $2.17\left(\mathrm{~m}_{\mathrm{c}}, 1 \mathrm{H}, 1-\mathrm{H}\right), 3.29$ (dd, $J=2.5$, $4.8 \mathrm{~Hz}, 1 \mathrm{H}, 6-\mathrm{H}), 3.56\left(\mathrm{~m}_{\mathrm{c}}, 1 \mathrm{H}, 4-\mathrm{CH}_{2}\right), 3.70(\mathrm{~B}$ part of ABX system, $\left.J_{\mathrm{AX}}=8.5 \mathrm{~Hz}, J_{\mathrm{AB}}=10.7 \mathrm{~Hz}, 1 \mathrm{H}, 4-\mathrm{CH}_{2}\right), 3.81$ (A part of ABX-system, $\left.J_{\mathrm{AX}}=3.0 \mathrm{~Hz}, J_{\mathrm{AB}}=12.0 \mathrm{~Hz}, 1 \mathrm{H}, 9-\mathrm{H}\right), 3.87$ (d, $J=13.9 \mathrm{~Hz}, 1 \mathrm{H}, \mathrm{NCH}_{2}$ ), 3.93 (B part of ABX system, $\left.J_{\mathrm{AB}}=12.0 \mathrm{~Hz}, 1 \mathrm{H}, 9-\mathrm{H}\right)^{*}, 3.94(\mathrm{~d}, J=11.4 \mathrm{~Hz}, 1 \mathrm{H}, 10-\mathrm{OH})$, $4.17\left(\mathrm{~d}, J=13.9 \mathrm{~Hz}, 1 \mathrm{H}, \mathrm{NCH}_{2}\right), 4.33(\mathrm{dt}, J \approx 1.0,2.5 \mathrm{~Hz}, 1 \mathrm{H}$, 5-H), 4.40-4.44 (m, 2H, 4-H, 10-H), 7.27-7.28, 7.32-7.36 (2 m, $5 \mathrm{H}, \mathrm{Ph}) \mathrm{ppm}, *$ no BX coupling present; ${ }^{13} \mathrm{C} \mathrm{NMR}(175 \mathrm{MHz}$, $\left.\mathrm{CDCl}_{3}\right) \delta-4.9,-4.4$ (2 q, SiMe), 18.1 (s, $\mathrm{SiCMe}_{3}$ ), 24.9 (q, $\mathrm{Me}), 25.9$ (q, $\left.\mathrm{SiCMe}_{3}\right), 34.6$ (q, Me), 47.4 (d, C-1), 58.4 (t, $\left.\mathrm{NCH}_{2}\right), 63.6\left(\mathrm{t}, 4-\mathrm{CH}_{2}\right), 64.5$ (d, C-5), 68.6 (t, C-9), 71.1 (d, C-6), 72.8 (d, C-10), 75.7 (d, C-4), 78.3 (s, C-2), 127.6, 128.3, 128.6, 137.3 (3 d, s, Ph) ppm; IR (ATR) $\widetilde{v}: 3570,3435(\mathrm{OH})$, 3085-3030 (=C-H), 2990-2855 (C-H), 1250, 1215 (C-O), 1060, 1040 (C-O-C) $\mathrm{cm}^{-1}$; ESI-TOF $(\mathrm{m} / \mathrm{z}):[\mathrm{M}+\mathrm{H}]^{+}$calcd for $\mathrm{C}_{23} \mathrm{H}_{40} \mathrm{NO}_{5} \mathrm{Si}$, 438.2670; found, 438.2702; anal. calcd for $\mathrm{C}_{23} \mathrm{H}_{39} \mathrm{NO}_{5} \mathrm{Si}$ (437.6): C, 63.12; H, 8.98; N, 3.20; found: $\mathrm{C}$, 62.68; H, 8.96; N, 3.09 .

\section{Typical procedure for deprotection using TBAF (procedure 4)}

$(1 S, 4 S, 5 S, 6 R, 10 S)-7-B$ enzyl-4-(hydroxymethyl)-2,2dimethyl-3,8-dioxa-7-azabicyclo[4.3.1]decan-5,10-diol (14): The TBS-protected alcohol (200 $\mathrm{mg}, 0.457 \mathrm{mmol})$ was dissolved in THF $(11 \mathrm{~mL})$ and the solution was cooled to $0{ }^{\circ} \mathrm{C}$. After addition of TBAF ( $1 \mathrm{M}$ in THF; $0.9 \mathrm{~mL}, 0.90 \mathrm{mmol})$, the reaction mixture was stirred at this temperature for $10 \mathrm{~min}$. Then the mixture was quenched with water $(5 \mathrm{~mL})$ and extracted with EtOAc $(3 \times 20 \mathrm{~mL})$. The combined organic layers were washed with brine, dried with $\mathrm{Na}_{2} \mathrm{SO}_{4}$, filtered through cotton and the solvent was removed in vacuo. The crude material (yellow oil, $224 \mathrm{mg}$ ) was purified by column chromatography (silica gel, hexanes/EtOAc 1:2 to pure EtOAc) to yield $14(135 \mathrm{mg}, 91 \%)$ as a colorless solid; mp 50-53 ${ }^{\circ} \mathrm{C}$; $[\alpha]_{\mathrm{D}}{ }^{22}-52.5$ ( c 0.6, MeOH); TLC (silica gel, hexanes/EtOAc 1:3): $R_{\mathrm{f}} 0.27 ;{ }^{1} \mathrm{H}$ NMR $\left(700 \mathrm{MHz}, \mathrm{CD}_{3} \mathrm{OD}\right) \delta 1.31,1.49(2 \mathrm{~s}$, $3 \mathrm{H}$ each, Me), $2.13\left(\mathrm{~m}_{\mathrm{c}}, 1 \mathrm{H}, 1-\mathrm{H}\right), 3.34$ (dd, $J=3.0,5.0 \mathrm{~Hz}, 1 \mathrm{H}$,
6-H), 3.63, 3.71 (AB part of ABX system, $J_{\mathrm{AX}}=3.5 \mathrm{~Hz}$, $J_{\mathrm{BX}}=6.5 \mathrm{~Hz}, J_{\mathrm{AB}}=11.0 \mathrm{~Hz}, 1 \mathrm{H}$ each, $\left.4-\mathrm{CH}_{2}\right), 3.74(\mathrm{dd}$, $J=3.0,12.8 \mathrm{~Hz}, 1 \mathrm{H}, 9-\mathrm{H}), 3.91$ (d, $\left.J=14.1 \mathrm{~Hz}, 1 \mathrm{H}, \mathrm{NCH}_{2}\right)$, $3.96(\mathrm{~d}, J=12.8 \mathrm{~Hz}, 1 \mathrm{H}, 9-\mathrm{H}), 4.12(\mathrm{~d}, J=14.1 \mathrm{~Hz}, 1 \mathrm{H}$, $\left.\mathrm{NCH}_{2}\right), 4.44-4.47$ (m, 3H, 4-H, 5-H, 10-H), 7.22, 7.29, 7.35 ( $\left.3 \mathrm{~m}_{\mathrm{c}}, 1 \mathrm{H}, 2 \mathrm{H}, 2 \mathrm{H}, \mathrm{Ph}\right) \mathrm{ppm} ;{ }^{13} \mathrm{C} \mathrm{NMR}\left(175 \mathrm{MHz}, \mathrm{CD}_{3} \mathrm{OD}\right)$

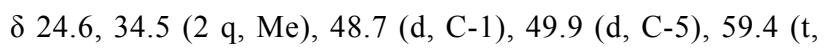
$\mathrm{NCH}_{2}$ ), $63.6\left(\mathrm{t}, 4-\mathrm{CH}_{2}\right), 65.9$ (t, C-9), 70.0 (d, C-4), 74.7 (d, C-6), 76.3 (d, C-10), 79.1 (s, C-2), 128.1, 129.2, 129.4, 139.2 (3 d, s, Ph) ppm; IR (ATR) $\widetilde{v}: 3360(\mathrm{OH}), 3085-3030(=\mathrm{C}-\mathrm{H})$, 2970-2860 (C-H), 1215 (C-O), 1060 (C-O-C) cm ${ }^{-1}$; ESI-TOF $(m / z):[\mathrm{M}+\mathrm{Na}]^{+}$calcd for $\mathrm{C}_{17} \mathrm{H}_{25} \mathrm{NO}_{5} \mathrm{Na}, 346.1630$; found, 346.1622; anal. calcd for $\mathrm{C}_{17} \mathrm{H}_{25} \mathrm{NO}_{5}$ (323.4): $\mathrm{C}, 63.14 ; \mathrm{H}$, 7.79 ; N, 4.33; found: C, 63.20; H, 7.83; N, 4.31 .

Synthesis of $(1 R, 4 S, 5 S, 6 S)$-4-(azidomethyl)-7-benzyl-5-(tertbutyldimethylsiloxy)-2,2-dimethyl-3,8-dioxa-7-azabicyclo[4.3.1]decan-10-one (23): Under argon atmosphere TPP (99 $\mathrm{mg}, 0.38 \mathrm{mmol})$ was dissolved in dry THF $(1.5 \mathrm{~mL})$ and the solution was cooled to $-20{ }^{\circ} \mathrm{C}$. DIAD $(76.5 \mathrm{mg}, 0.378 \mathrm{mmol})$ was added and the reaction mixture became milky white. After $10 \mathrm{~min}$ stirring at that temperature, alcohol 11 (150 mg, $0.344 \mathrm{mmol}$ in $0.6 \mathrm{~mL}$ of dry THF) was slowly added and the mixture was stirred for further $30 \mathrm{~min}$ at $-20{ }^{\circ} \mathrm{C}$. The now milky-yellow solution was progressively warmed to $0{ }^{\circ} \mathrm{C}$ and DPPA $(89.0 \mu \mathrm{L}, 0.413 \mathrm{mmol})$ was added. After stirring for $6 \mathrm{~h}$ at $0{ }^{\circ} \mathrm{C}$ and $1 \mathrm{~d}$ at $\mathrm{rt}$, the reaction mixture was quenched with water $(2 \mathrm{~mL})$ and extracted with EtOAc $(3 \times 5 \mathrm{~mL})$. The combined organic layers were washed with brine, dried with $\mathrm{Na}_{2} \mathrm{SO}_{4}$, filtered through cotton and the solvent was removed in vacuo. Crude material (yellow oil, $479 \mathrm{mg}$ ) was purified by column chromatography (silica gel, hexanes to hexanes/EtOAc $8: 1)$ to yield azide $23(125 \mathrm{mg}, 79 \%)$ as a colorless solid; $\mathrm{mp}$ $117-121{ }^{\circ} \mathrm{C} ;[\alpha]_{\mathrm{D}}{ }^{22}+22.7\left(c 1.01, \mathrm{CHCl}_{3}\right)$; TLC (silica gel, hexanes/EtOAc 3:1) $R_{\mathrm{f}} 0.73 ;{ }^{1} \mathrm{H}$ NMR $\left(500 \mathrm{MHz}, \mathrm{CDCl}_{3}\right)$ $\delta-0.11,-0.03$ ( $2 \mathrm{~s}, 3 \mathrm{H}$ each, SiMe), 0.86 (s, 9H, Sit-Bu), 1.37, 1.42 ( $2 \mathrm{~s}, 3 \mathrm{H}$ each, Me), 2.55 (t, $J \approx 2.8 \mathrm{~Hz}, 1 \mathrm{H}, 1-\mathrm{H}), 3.05$ (dd, $\left.J=4.3,12.3 \mathrm{~Hz}, 1 \mathrm{H}, 4-\mathrm{CH}_{2}\right), 3.36(\mathrm{dd}, J=1.1,2.8 \mathrm{~Hz}, 1 \mathrm{H}$, 6-H), 3.45 (dd, $J=8.7,12.3 \mathrm{~Hz}, 1 \mathrm{H}, 4-\mathrm{CH}_{2}$ ), 3.95 (A part of $\mathrm{AB}$ system, $\left.J_{\mathrm{AB}}=13.5 \mathrm{~Hz}, 1 \mathrm{H}, \mathrm{NCH}_{2}\right), 4.05\left(\mathrm{~m}_{\mathrm{c}}, 1 \mathrm{H}, 5-\mathrm{H}\right)$, 4.14 (B part of AB system, $\left.J_{\mathrm{AB}}=13.5 \mathrm{~Hz}, 1 \mathrm{H}, \mathrm{NCH}_{2}\right), 4.18$ $\left(\mathrm{m}_{\mathrm{c}}, 2 \mathrm{H}, 9-\mathrm{H}\right), 4.61$ (ddd, $\left.J=0.8,4.3,8.7 \mathrm{~Hz}, 1 \mathrm{H}, 4-\mathrm{H}\right)$, 7.27-7.35 (m, 5H, Ph) ppm; ${ }^{13} \mathrm{C} \mathrm{NMR}\left(125 \mathrm{MHz}, \mathrm{CDCl}_{3}\right)$ $\delta-4.8,-4.6$ (2 q, SiMe), 18.2 (s, $\mathrm{SiCMe}_{3}$ ), 22.4 (q, Me), 25.8 (q, $\left.\mathrm{SiCMe}_{3}\right), 31.6$ (q, Me), $53.2\left(\mathrm{t}, 4-\mathrm{CH}_{2}\right), 58.1$ (d, C-1), 58.7 (t, $\left.\mathrm{NCH}_{2}\right), 67.9$ (t, C-9), 69.4 (d, C-5), 74.2 (d, C-4), 75.0 (s, C-2), 75.1 (d, C-6), 127.9, 128.66, 128.71, 136.2 (3 d, s, Ph), 199.8 (s, C-10) ppm; IR (ATR) $\widetilde{v}: 3090-3030(=\mathrm{C}-\mathrm{H})$, 2855-2995 (C-H), $2095\left(\mathrm{~N}_{3}\right), 1710(\mathrm{C}=\mathrm{O}), 1495(\mathrm{C}=\mathrm{C}), 1295$, 1255 (C-O), 1190-1075 (C-O-C) $\mathrm{cm}^{-1}$; ESI-TOF $(\mathrm{m} / \mathrm{z})$ : $[\mathrm{M}+\mathrm{H}]^{+}$calcd for $\mathrm{C}_{23} \mathrm{H}_{37} \mathrm{~N}_{4} \mathrm{O}_{4} \mathrm{Si}$, 461.2579; found, 461.2607. 


\section{Typical procedure for hydrogenolysis with $\mathrm{Pd} / \mathrm{C}$ in $\mathrm{AcOH} / \mathrm{MeOH}$ (procedure 5)}

(2S,3S,4R,5S,6S)-4-Amino-2,6-bis(hydroxymethyl)-7,7dimethyloxepan-3,5-diol (26): Bicyclic compound 14 (100 mg, $0.309 \mathrm{mmol})$ was dissolved in dry $\mathrm{MeOH}(10 \mathrm{~mL})$ and $\mathrm{AcOH}$ $(2 \mathrm{~mL})$. After addition of $\mathrm{Pd} / \mathrm{C}(100 \mathrm{mg}, 0.094 \mathrm{mmol} \mathrm{Pd})$ the suspension was saturated with hydrogen at $\mathrm{rt}$ for $1 \mathrm{~h}$ followed by stirring under hydrogen pressure (balloon). After reaction completion $18 \mathrm{~h}$, the mixture was filtered through Celite ${ }^{\circledR}$, washed with $\mathrm{EtOH}$ and the solvents were removed in vacuo. The obtained salt was dissolved in water and filtered through a DOWEX ${ }^{\circledR}$ column $\left(\mathrm{H}_{2} \mathrm{O}\right)$ and washed with water until the complete acid was removed (control with $\mathrm{pH}$ paper). Then the column was washed with aq $\mathrm{NH}_{3}$ ( 2 to $5 \%$ ) to yield the free amine 26 (65 mg, 90\%) as a colorless solid; $\mathrm{mp} 121-125^{\circ} \mathrm{C}$; $[\alpha]_{\mathrm{D}}^{22}+10.2(c 1.35, \mathrm{MeOH}) ;$ TLC [silica gel, $\mathrm{MeCN} / \mathrm{aq} \mathrm{NH}_{3}$ (25\%) 5:1] $R_{\mathrm{f}} 0.10 ;{ }^{1} \mathrm{H}$ NMR (700 MHz, $\left.\mathrm{CD}_{3} \mathrm{OD}\right) \delta 1.19,1.34$ ( $2 \mathrm{~s}, 3 \mathrm{H}$ each, Me), 1.77 (ddd, $J=3.0,6.5,9.5 \mathrm{~Hz}, 1 \mathrm{H}, 6-\mathrm{H})$, $2.89(\mathrm{dd}, J=6.9,8.8 \mathrm{~Hz}, 1 \mathrm{H}, 4-\mathrm{H}), 3.52-3.55\left(\mathrm{~m}, 2 \mathrm{H}, 2-\mathrm{CH}_{2}\right.$, $3-\mathrm{H}$ ), 3.59 (B part of ABX system, $J_{\mathrm{BX}}=5.0 \mathrm{~Hz}$, $\left.J_{\mathrm{AB}}=11.5 \mathrm{~Hz}, 1 \mathrm{H}, 2-\mathrm{CH}_{2}\right), 3.65,3.68(\mathrm{AB}$ part of $\mathrm{ABX}$ system, $J_{\mathrm{AX}}=3.0 \mathrm{~Hz}, J_{\mathrm{BX}}=6.5 \mathrm{~Hz}, J_{\mathrm{AB}}=11.3 \mathrm{~Hz}, 1 \mathrm{H}$ each, 6- $\left.\mathrm{CH}_{2}\right), 3.71\left(\mathrm{~m}_{\mathrm{c}}, 2 \mathrm{H}, 2-\mathrm{H}, 5-\mathrm{H}\right) \mathrm{ppm} ;{ }^{13} \mathrm{C} \mathrm{NMR}(175 \mathrm{MHz}$, $\left.\mathrm{CD}_{3} \mathrm{OD}\right) \delta 21.1,31.5(2 \mathrm{q}, \mathrm{Me}), 60.0(\mathrm{~d}, \mathrm{C}-6), 63.6\left(\mathrm{t}, 2-\mathrm{CH}_{2}\right)$, 64.1 (d, C-4), 64.2 (t, 2-CH $), 71.3,73.8$ (2 d, C-2, C-5), 76.5 (d, C-3), 77.1 (s, C-7) ppm; IR (ATR) $\widetilde{v}: 3530-3310(\mathrm{OH}$, $\left.\mathrm{NH}_{2}\right), 2960-2860$ (C-H), 1455, 1470, 1140 (C-O) cm ${ }^{-1}$; ESI-TOF $(\mathrm{m} / \mathrm{z})$ : $[\mathrm{M}+\mathrm{Na}]^{+}$calcd for $\mathrm{C}_{10} \mathrm{H}_{21} \mathrm{NO}_{5} \mathrm{Na}, 258.1320$; found, 258.1317; anal. calcd for $\mathrm{C}_{10} \mathrm{H}_{21} \mathrm{NO}_{5}$ (235.3): C, 51.05; H, 9.00; N, 5.95; found, C, 50.78; H, 8.97; N: 5.59.

\section{Supporting Information}

\section{Supporting Information File 1 \\ Experimental procedures. \\ [http://www.beilstein-journals.org/bjoc/content/ \\ supplementary/1860-5397-10-17-S1.pdf]}

\section{Supporting Information File 2}

Characterization data ${ }^{1} \mathrm{H}$ NMR and ${ }^{13} \mathrm{C}$ NMR spectra of synthesized compounds.

[http://www.beilstein-journals.org/bjoc/content/ supplementary/1860-5397-10-17-S2.pdf]

\section{Acknowledgements}

This work was generously supported by the Deutsche Forschungsgemeinschaft (Sonderforschungsbereich SFB 765), the Center of International Cooperation of the Freie Universität Berlin and Bayer HealthCare. We thank Dr. A. Al-Harrasi for preliminary experiments and N. Danneberg, M. Menger and L.
Selter for experimental assistance. We acknowledge valuable discussions and help during preparation of the manuscript by Dr. R. Zimmer and J. Salta.

\section{References}

1. Wong, C.-H. Carbohydrate-based Drug Discovery; Wiley-VCH: Weinheim, Germany, 2003; Vol. 1.

2. Sears, P.; Wong, C.-H. Angew. Chem. 1999, 111, 2446-2471. doi:10.1002/(SICI)1521-3757(19990816)111:16<2446::AID-ANGE2446 $>3.0 . \mathrm{CO} ; 2-4$

Angew. Chem., Int. Ed. 1999, 38, 2300-2324.

doi:10.1002/(SICI)1521-3773(19990816)38:16<2300::AID-ANIE2300>3 .0.CO;2-6

3. Koester, D. C.; Holkenbrink, A.; Werz, D. B. Synthesis 2010, 3217-3242. doi:10.1055/s-0030-1258228

4. Lee, Y. C.; Lee, R. T. Acc. Chem. Res. 1995, 28, 321-327. doi:10.1021/ar00056a001

5. Lundquist, J. J.; Toone, E. J. Chem. Rev. 2002, 102, 555-578. doi:10.1021/cr000418f

6. Kakinuma, K.; Ikekawa, N.; Nakagawa, A.; Omura, S. J. Am. Chem. Soc. 1979, 101, 3402-3404. doi:10.1021/ja00506a056

7. Funel-Le Bon, C.; Berrué, F.; Thomas, O. P.; Reyes, F.; Amade, P. J. Nat. Prod. 2005, 68, 1284-1287. doi:10.1021/np050100o

8. Saha, J.; Peczuh, M. W. Synthesis and properties of septanose carbohydrates. In Advances in Carbohydrate Chemistry and Biochemistry; Derek, H., Ed.; Elsevier: Amsterdam, The Netherlands, 2011; Vol. 66, pp 121-186. doi:10.1016/B978-0-12-385518-3.00003-1

9. Sahabuddin, S.; Roy, A.; Drew, M. G. B.; Roy, B. G.; Achari, B.; Mandal, S. B. J. Org. Chem. 2006, 71, 5980-5992. doi:10.1021/jo0606554

10. Tripathi, S.; Roy, B. G.; Drew, M. G. B.; Achari, B.; Mandal, S. B. J. Org. Chem. 2007, 72, 7427-7430. doi:10.1021/jo070846m

11. Bhattacharjee, A.; Datta, S.; Chattopadhyay, P.; Ghoshal, N.; Kundu, A. P.; Pal, A.; Mukhopadhyay, R.; Chowdhury, S.; Bhattacharjya, A.; Patra, A. Tetrahedron 2003, 59, 4623-4639. doi:10.1016/S0040-4020(03)00634-3

12. Hoberg, J. O. Tetrahedron 1998, 54, 12631-12670. doi:10.1016/S0040-4020(98)00596-1

13. Kotkar, D.; Ghosh, P. K. J. Chem. Soc., Chem. Commun. 1986, 650-651. doi:10.1039/C39860000650

14. Pavlik, C.; Onorato, A.; Castro, S.; Morton, M.; Peczuh, M. W.; Smith, M. B. Org. Lett. 2009, 11, 3722-3725. doi:10.1021/ol9013427

15. Snyder, N. L.; Haines, H. M.; Peczuh, M. W. Tetrahedron 2006, 62, 9301-9320. doi:10.1016/j.tet.2006.07.021

16. Peczuh, M. W.; Snyder, N. L. Tetrahedron Lett. 2003, 44, 4057-4061. doi:10.1016/S0040-4039(03)00849-9

17. Castro, S.; Johnson, C. S.; Surana, B.; Peczuh, M. W. Tetrahedron 2009, 65, 7921-7926. doi:10.1016/j.tet.2009.07.041

18. Riley, D. L.; van Otterlo, W. A. L. Oxepines and Azepines. In Heterocycles in Natural Product Synthesis; Majumdar, K. C.; Chattopadhyay, S. K., Eds.; Wiley-VCH: Weinheim, Germany, 2011; pp 535-568. doi:10.1002/9783527634880

See for a recent review about oxepines in natural product synthesis.

19. Fyvie, W. S.; Morton, M.; Peczuh, M. W. Carbohydr. Res. 2004, 339, 2363-2370. doi:10.1016/j.carres.2004.07.009

20. Wong, J. C. Y.; Lacombe, P.; Sturino, C. F. Tetrahedron Lett. 1999, 40, 8751-8754. doi:10.1016/S0040-4039(99)01881-X

21. Ganesh, N. V.; Jayaraman, N. J. Org. Chem. 2007, 72, 5500-5504. doi:10.1021/jo070444e 
22. Ganesh, N. V.; Jayaraman, N. J. Org. Chem. 2009, 74, 739-746. doi:10.1021/j0801967s

23. Al-Harrasi, A.; Reissig, H.-U. Angew. Chem. 2005, 117, 6383-6387. doi:10.1002/ange.200501127

Angew. Chem., Int. Ed. 2005, 44, 6227-6231.

doi:10.1002/anie.200501127

24. Al-Harrasi, A.; Pfrengle, F.; Prisyazhnyuk, V.; Yekta, S.; Koóš, P.; Reissig, H.-U. Chem.-Eur. J. 2009, 15, 11632-11641. doi:10.1002/chem.200900996

25. Pfrengle, F.; Reissig, H.-U. Chem.-Eur. J. 2010, 16, 11915-11925. doi:10.1002/chem.201001060

26. Pfrengle, F.; Lentz, D.; Reissig, H.-U. Angew. Chem. 2009, 121, 3211-3215. doi:10.1002/ange.200805724

Angew. Chem., Int. Ed. 2009, 48, 3165-3169 doi:10.1002/anie.200805724

27. Pfrengle, F.; Reissig, H.-U. Chem. Soc. Rev. 2010, 39, 549-557. doi:10.1039/b914356d

28. Bouché, L.; Reissig, H.-U. Pure Appl. Chem. 2012, 84, 23-36. doi:10.1351/PAC-CON-11-09-20

29. Dondoni, A.; Franco, S.; Junquera, F.; Merchán, F. L.; Merino, P.; Tejero, T. Synth. Commun. 1994, 24, 2537-2550. doi:10.1080/00397919408010565

30. Dondoni, A.; Franco, S.; Junquera, F.; Merchán, F. L.; Merino, P.; Tejero, T.; Bertolasi, V. Chem.-Eur. J. 1995, 1, 505-520. doi:10.1002/chem.19950010804

31. Helms, M.; Schade, W.; Pulz, R.; Watanabe, T.; Al-Harrasi, A.; Fišera, L.; Hlobilová, I.; Zahn, G.; Reissig, H.-U. Eur. J. Org. Chem. 2005, 1003-1019. doi:10.1002/ejoc.200400627

32. Brasholz, M.; Reissig, H.-U.; Zimmer, R. Acc. Chem. Res. 2009, 42, 45-56. doi:10.1021/ar800011h

33. Dernedde, J.; Enders, S.; Reissig, H.-U.; Roskamp, M.; Schlecht, S.; Yekta, S. Chem. Commun. 2009, 932-934. doi:10.1039/b818263a

34. Roskamp, M.; Enders, S.; Pfrengle, F.; Yekta, S.; Dekaris, V.; Dernedde, J.; Reissig, H.-U.; Schlecht, S. Org. Biomol. Chem. 2011, 9, 7448-7456. doi:10.1039/C1OB05583F

35. Abushanab, E.; Vemishetti, P.; Leiby, R. W.; Singh, H. K.; Mikkilineni, A. B.; Wu, D. C.-J.; Saibaba, R.; Panzica, R. P J. Org. Chem. 1988, 53, 2598-2602. doi:10.1021/jo00246a037

36. The ethyl ester was obtained as mixture of diastereomers (52:48), see Supporting Information.

37. Al-Harrasi, A. New Transformations of Enantiopure 3,6-Dihydro-2H-1,2-oxazines: Ring Cleavages, Ring Enlargements and a Novel Approach to Carbohydrate Mimetics. Ph.D. Thesis, Freie Universität Berlin, Germany, 2005.

38. Dondoni, A.; Junquera, F.; Merchan, F. L.; Merino, P.; Tejero, T. Synthesis 1994, 1450-1456. doi:10.1055/s-1994-25712

39. Merino, P.; Lanaspa, A.; Merchan, F. L.; Tejero, T. J. Org. Chem. 1996, 61, 9028-9032. doi:10.1021/jo961293a

40. Fujiwara, K.; Amano, A.; Tokiwano, T.; Murai, A. Tetrahedron 2000, 56, 1065-1080. doi:10.1016/S0040-4020(00)00009-0

41. Phillips, A. J.; Morris, J. C.; Abell, A. D. Tetrahedron Lett. 2000, 41, 2723-2727. doi:10.1016/S0040-4039(00)00248-3

42. These results were confirmed by X-ray analysis, see ref [37] and [49].

43. We assume that the hydride reagent also attacks the Re-side, as in the previous reductions (see Scheme 4 and Scheme 5). NMR data of the corresponding alcohol are in accordance with this assignment.

44. Conditions used were analogous to procedures in ref [24].
45. Moinizadeh, N.; Klemme, R.; Kansy, M.; Zimmer, R.; Reissig, H.-U. Synthesis 2013, 45, 2752-2762. doi:10.1055/s-0033-1339509 See for Click reactions using 1,2-oxazines which were recently described by our group.

46. Lal, B.; Pramanik, B. N.; Manhas, M. S.; Bose, A. K. Tetrahedron Lett. 1977, 18, 1977-1980. doi:10.1016/S0040-4039(01)83657-1

47. Bressel, B.; Egart, B.; Al-Harrasi, A.; Pulz, R.; Reissig, H.-U.; Brüdgam, I. Eur. J. Org. Chem. 2008, 467-474. doi:10.1002/ejoc.200700792

48. Jasiński, M.; Lentz, D.; Moreno-Clavijo, E.; Reissig, H.-U. Eur. J. Org. Chem. 2012, 3304-3316. doi:10.1002/ejoc.201200158

49. Al-Harrasi, A.; Brüdgam, I.; Hartl, H.; Reissig, H.-U. Z. Kristallogr. NCS 2006, 221, 131-132.

See for an X-ray analysis of the corresponding TBS-protected oxepane of 27.

50. Smith, G. V.; Notheisz, F. Hydrogenolysis of Benzyl-Nitrogen Bonds. Heterogeneous Catalysis in Organic Chemistry; Academic Press, 1999; pp 171-172.

51. Fu, X.; Cook, J. M. J. Am. Chem. Soc. 1992, 114, 6910-6912. doi:10.1021/ja00043a043

52. Fu, X.; Cook, J. M. J. Org. Chem. 1993, 58, 661-672. doi:10.1021/jo00055a019

53. The same type of side products was also obtained in our group: Zimmer, R.; Kandziora, M.; Salta, J. unpublished results.

54. Su, J.-K.; Jia, Y.-M.; He, R.; Rui, P.-X.; Han, N.; He, X.; Xiang, J.; Chen, X.; Zhu, J.; Yu, C.-Y. Synlett 2010, 1609-1616. doi:10.1055/s-0029-1258085

\section{License and Terms}

This is an Open Access article under the terms of the Creative Commons Attribution License (http://creativecommons.org/licenses/by/2.0), which permits unrestricted use, distribution, and reproduction in any medium, provided the original work is properly cited.

The license is subject to the Beilstein Journal of Organic Chemistry terms and conditions:

(http://www.beilstein-journals.org/bjoc)

The definitive version of this article is the electronic one which can be found at: $\underline{\text { doi: } 10.3762 / \text { bjoc. } 10.17}$ 